\title{
Type 1 Interferon Dynamics in Bacterial Infection
}

\author{
Tania Rahman ${ }^{1 *}$ and Ferdous Seraj ${ }^{2}$ \\ ${ }^{1}$ Department of Biochemistry and Molecular Biology, Bio21 Molecular Science and \\ Biotechnology Institute, University of Melbourne, Australia \\ ${ }^{2}$ School of Civil, Environmental and Chemical Engineering, RMIT University, \\ Melbourne, Australia
}

\section{Review Article \\ Volume 2 Issue 3}

Received Date: October 29, 2018

Published Date: December 02, 2018

DOI: $10.23880 /$ jidtm- 16000120

*Corresponding author: Tania Rahman, Department of Biochemistry and Molecular Biology, Bio21 Molecular Science and Biotechnology Institute, University of Melbourne, Melbourne, Victoria, Australia, Email: tania.rahman@du.ac.bd

\section{Abstract}

Several reports have demonstrated that bacteria can induce type I interferon in infected cells and that IFN-I may help control bacterial infection. Moreover, type I IFN play an essential role in the immune homeostasis of gastrointestinal tract and maintain barrier integrity in endothelial cells. Also pDC produce large amount of type I IFN due to their constitutive expression of the transcription factor IRF-7. The work presented here has unravelled the potential of type 1 IFN in the immune system including various subtypes, their production by different cell types and their host defense against bacterial pathogens. These findings would help set up future avenues of research to elucidate a key mechanism of action of these cells and provide new therapeutic insights.

Keywords: IFNAR1; IFNAR2; pDC; ISG; TLR4-TRIF pathway; TLR4-TRIF pathway; IFNAR1\%- mice

\section{Introduction}

Interferons (IFN) are a heterogeneous class of soluble immune mediators which were discovered 50 year ago and named for their potent ability to "interfere" with viral replication [1,2]. The IFN family is primarily classified into three main subclasses - type I, type II and type III IFNs. In humans and mice, the type I IFN family consists of 16 members including IFN $\beta$, IFN $\varepsilon$, IFNא and IFN $\omega$ and 12 IFN $\alpha$ subtypes [3]. All type I IFN bind to a ubiquitously expressed heterodimeric receptor encompassing two common chains, IFNAR1 and IFNAR2 [4-6]. Once type I IFN bind to its receptor, it activates a signalling cascade including JAK/STAT pathway [7] to induce various type I interferon inducible genes (ISG), such as 2-5 oas, Isg15,Irgm, Pkr [8-11]. The biological functions of these ISGs include antiviral, antibacterial, antiproliferative and immunomodulatory [12].

\section{Production of Type 1 IFN}

Type I IFNs can be produced by different cells, comprising leukocytes, fibroblasts and endothelial cells and the mechanisms by which pathogens are sensed can be different. Type I IFN is mainly produced in response to pathogen recognition receptor, such as TLR, NLR, RIG-I, AIM2, cGas and STING $[13,14]$. The signalling cascades that prime the induction of type I IFNs may vary according to the stimulus or the responding cell types [3]. For instance, ssRNA viruses or host cell products induce type I interferon production in pDCs, cDCs and macrophages through TLR7-MyD88 and TLR8-MyD88 pathway. dsRNA viruses induce type I interferon production in macrophages, cDCs and epithelial cells through TLR3-TRIF and RIG-1 pathway [15]. Gram negative bacteria induce type I interferon production in the macrophages and cDCs through TLR4-TRIF pathway 
binding to LPS [16-19]. CpG DNA derived from bacteria or viruses induce type I interferon secretion in pDCs, cDCs and macrophages through TLR9-MyD88 pathway $[20,17]$.

\section{The Antibacterial Response}

Type I IFNs are recognized for their induction of robust antiviral immune responses. The role of type I IFNs in response to viral infection is variable and they exhibit multiple modes of action, such as inhibition of protein synthesis, induction of apoptosis and initiation of inflammatory responses. During bacterial infections, type I interferon can be protective or detrimental to the host, though little is known about their potential in bacterial infections [21]. Type I interferon can contribute to host resistance in bacterial infections by inducing proinflammatory cytokines, triggering DCs, inducing secretion of antibodies, or inducing antimicrobial effectors [22]. Also they can impair host response by inducing apoptosis, suppressing proinflammatory cytokines, producing IL-10 and IL-1 receptor antagonist or restricting host responses to IFN $\gamma$ during bacterial attack [23].

In bacterial infections, the functions of type I interferon are pleiotropic and do not always favour the immune response of the host against the infection. For instance, type I interferon impairs Chlamydia growth cycle resulting in chronic infection [24]. Also, IFNAR1 $\%$ mice are protected against Chlamydia muridarum infection, exhibiting extended survival and decreased bacterial burdens compared to wild-type control [25]. In Legionnaires' disease, type I IFN plays a role in restricting L. pneumophila replication in macrophages [26,27]. For instance, IFNAR1 $\%$ mice have been found to have higher bacterial loads compared to wild-type mice [28] while others have found that type I interferon do not influence the colonization of L.pneumophila in mice [29]. Type I IFN has been found to protect mice during Salmonella typhimurium infection [30]. However, recently, it has been shown that type1 interferon is harmful to the host during S. typhimurium infection [31]. Also, Type I interferon can reduce cellular invasion by gut bacteria, including Shigellaflexneriand Salmonella enterica $[32,33]$.

The production of type I IFN during Listeria monocytogenes infections has been found detrimental to the host [34-38]. For instance, IFNAR1 $\%$ mice are resistant to $L$. monocytogenes infection, with a greater survival rates, and lower Listeria titres in spleen and liver than wild-type mice and CD11b+DCs tend to be one of the major IFN $\beta$-producing cells [39]. Similarly to infection with L. monocytogenes, type I interferons have been shown to be involved in the apoptosis of macrophages during $F$. novicidainfection [40]. In addition, type I IFN signalling appears to be damaging to the host during infection with intracellular gram-positive bacteria Mycobacterium tuberculosis. M. tuberculosis infected IFNAR2 $\%$ mice have decreased mortality compared to WT [41-43].

Type I interferon is crucial for host resistance to some bacterial infections. For example, IFNAR-/mice exhibit decreased longevity and enhanced bacterial titres following infection with group B Streptococcus, Streptococcus pneumoniae, E. coli, Helicobacter pylori and Streptococcus pyogenes infections [44-47], as well as in a model of caecal ligation and puncture [48]. Type I IFNs have been shown to have adverse effects in peritoneal sepsis [49], in Staphylococcus aureus- induced [50], during Whipple's disease (caused by Tropheryma whipplei) [51], in Brucella abortus infection [52], during infection with the plague agent Yersinia pestis [53], in Francisellatularensis induced respiratoryinfection [54]. In all these models, IFNAR $/$-mice are reportedly more resistant to infection than wild type controls.

\section{Concluding Remarks}

The large number of recent studies on type I interferon indicates that type I IFNs have an extensive array of immunomodulatory properties upon infection with bacteria. The study of how bacteria interact with the IFN system has told us much about bacterial pathogenesis and about the IFN system itself. Thus the role of type I interferons in response to bacterial pathogen might be diverse including either beneficial or detrimental which needs to be fully understood.

\section{Disclosure}

The authors declare no competing interests.

\section{References}

1. Isaacs A, Lindenmann J (1957) Virus interference. I. The interferon. Proc R Soc Lond B Biol Sci 147:258267.

2. Nagano Y, Kojima Y (1958) Inhibition of vaccinia infection by a liquid factor in tissues infected by homologous virus. C R Seances Soc Biol Fil 152(11): 1627-1629.

3. González-Navajas JM, Lee J, David M, Raz E (2012) Immunomodulatory functions of type I interferons. Nat Rev Immunol 12: 125-135. 


\section{Journal of Infectious Diseases \& Travel Medicine}

4. Theofilopoulos AN, Baccala R, Beutler B, Kono DH(2005) Type I interferons (alpha/beta) in immunity and autoimmunity. Annu Rev Immunol 23: 307-336.

5. Li X, Leung S, Qureshi S, Darnell JE, Stark GR (1996) Formation of STAT1-STAT2 heterodimers and their role in the activation of IRF-1 gene transcription by interferon-alpha. J Biol Chem 271(10): 5790-5794.

6. Decker T, Müller M, Stockinger S (2005) The yin and yang of type I interferon activity in bacterial infection. Nat Rev Immunol5(9): 675-687.

7. Noppert SJ, Fitzgerald KA, Hertzog PJ (2007) The role of type I interferons in TLR responses. Immunol Cell Biol 85(6): 446-457.

8. Lenschow DJ, Lai C, Frias-Staheli N, Giannakopoulos NV, Lutz A, et al. (2007) IFN-stimulated gene 15 functions as a critical antiviral molecule against influenza, herpes, and Sindbis viruses. Proc Natl Acad Sci USA 104(4): 1371-1376.

9. Al-Khatib K, Williams BR, Silverman RH, Halford W, Carr DJ (2004) Distinctive roles for 2',5'oligoadenylate synthetases and double-stranded RNA-dependent protein kinase $\mathrm{R}$ in the in vivo antiviral effect of an adenoviral vector expressing murine IFN-beta. J Immunol 172(9): 5638-5647.

10. Howard J (2008) The IRG proteins: a function in search of a mechanism. Immunobiology 213(3-4): 367-375.

11. Khabar KS, Dhalla M, Siddiqui Y, Zhou A, Al-Ahdal MN, et al. (2000) Effect of deficiency of the doublestranded RNA-dependent protein kinase, PKR, on antiviral resistance in the presence or absence of ribonuclease L: HSV-1 replication is particularly sensitive to deficiency of the major IFN-mediated enzymes. J Interferon Cytokine Res 20(7): 653-659.

12. Hertzog P, Forster S, Samarajiwa S (2011) Systems biology of interferon responses. J Interferon Cytokine Res 31(1): 5-11.

13. Perry AK, Chen G, Zheng D, Tang H, Cheng G (2005) The host type I interferon response to viral and bacterial infections. Cell Res 15(6): 407-422.

14. Broz P, Monack DM (2013) Newly described pattern recognition receptors team up against intracellular pathogens. Nat Rev Immunol 13(8): 551-565.

15. Kawai T, Akira S (2008) Toll-like receptor and RIG-Ilike receptor signaling. Ann N Y Acad Sci 1143: 1-20.
16. Utaisincharoen $\mathrm{P}$, Anuntagool N, Limposuwan $\mathrm{K}$, Chaisuriya P, Sirisinha S (2003) Involvement of beta interferon in enhancing inducible nitric oxide synthase production and antimicrobial activity of Burkholderiapseudomallei-infected macrophages. Infect Immun 71(6): 3053-3057.

17. Sing A, Merlin T, Knopf HP, Nielsen PJ, Loppnow H, et al. (2000) Bacterial induction of beta interferon in mice is a function of the lipopolysaccharide component. Infect Immun 68(3): 1600-1607.

18. Eloranta ML, Sandberg K, Ricciardi-Castagnoli P, Lindahl M, Alm GV (1997) Production of interferonalpha/beta by murine dendritic cell lines stimulated by virus and bacteria. Scand J Immunol 46(3): 235241.

19. Yaegashi Y, Nielsen P, Sing A, Galanos C, Freudenberg MA (1995) Interferon beta, a cofactor in the interferon gamma production induced by gramnegative bacteria in mice. J Exp Med 181(3): 953-960.

20. Krieg AM (2002) CpG motifs in bacterial DNA and their immune effects. Annu Rev Immunol 20: 709760.

21. Macmicking JD (2012) Interferon-inducible effector mechanisms in cell-autonomous immunity. Nat Rev Immunol 12(5): 367-382.

22. Trinchieri G (2010) Type I interferon: friend or foe? J Exp Med 207(10): 2053-2063.

23. McNab F, Mayer Barber K, Sher A, Wack A, O'Garra A (2015) Type I interferons in infectious disease. Nat Rev Immunol 15(2): 87-103.

24. Ishihara T, Aga M, Hino K, Ushio C, Taniguchi M, et al. (2005) Inhibition of chlamydia trachomatis growth by human interferon-alpha: mechanisms and synergistic effect with interferon-gamma and tumor necrosis factor-alpha. Biomed Res 26(4): 179-185.

25. Hongyu Qiu, Yijun Fan, Antony George Joyee, Shuhe Wang, Xiaobing Han, et al. (2008) Type I IFNs enhance susceptibility to Chlamydia muridarum lung infection by enhancing apoptosis of local macrophages. J Immunol 181(3): 2092-2102.

26. Opitz B, Vinzing M, van Laak V, Schmeck B, Heine G, et al. (2006) Legionella pneumophila induces IFNbeta in lung epithelial cells via IPS-1 and IRF3, which also control bacterial replication. J Biol Chem 281(147): 36173-36179. 


\section{Journal of Infectious Diseases \& Travel Medicine}

27. Coers J, Vance RE, Fontana MF, Dietrich WF (2007) Restriction of Legionella pneumophila growth in macrophages requires the concerted action of cytokine and Naip5/Ipaf signalling pathways. Cell Microbiol 9(10): 2344-2357.

28. Plumlee CR, Lee C, Beg AA, Decker T, Shuman HA, et al. (2009) Interferons direct an effective innate response to Legionella pneumophila infection. J Biol Chem 284(44): 30058-30066.

29. Ang DK, Oates CV, Schuelein R, Kelly M, Sansom FM, et al. (2010) Cutting edge: pulmonary Legionella pneumophila is controlled by plasmacytoid dendritic cells but not type I IFN. J Immunol 184(10): 54295433.

30. Freudenberg MA, Merlin T, Kalis C, Chvatchko Y, Stübig H, et al. (2002) Cutting edge: a murine, IL-12independent pathway of IFN-gamma induction by gram-negative bacteria based on STAT4 activation by Type I IFN and IL-18 signaling. J Immunol 169(4): 1665-1668.

31. Robinson N, McComb S, Mulligan R, Dudani R, Krishnan L, et al. (2012) Type I interferon induces necroptosis in macrophages during infection with Salmonella entericaserovar Typhimurium. Nat Immunol 13(10): 954-962.

32. Niesel DW, Hess CB, Cho YJ, Klimpel KD, Klimpel GR (1986) Natural and recombinant interferons inhibit epithelial cell invasion by Shigella spp. Infect Immun 52(3): 828-833.

33. Bukholm G, Berdal BP, Haug C, Degré M (1984) Mouse fibroblast interferon modifies Salmonella typhimurium infection in infant mice. Infect Immun 45(1): 62-66.

34. Stockinger S, Materna T, Stoiber D, Bayr L, Steinborn $\mathrm{R}$, et al. (2002) Production of type I IFN sensitizes macrophages to cell death induced by Listeria monocytogenes. J Immunol 169(11): 6522-6599.

35. Auerbuch V, Brockstedt DG, Meyer-Morse N, O'Riordan M, Portnoy DA (2004) Mice lacking the type I interferon receptor are resistant to Listeria monocytogenes. J Exp Med 200(4): 527-533.

36. Carrero JA, Calderon B, Unanue ER (2004) Type I interferon sensitizes lymphocytes to apoptosis and reduces resistance to Listeria infection. J Exp Med $200(4): 535-540$.
37. O'connell RM, Saha SK, Vaidya SA, Bruhn KW, Miranda GA, et al. (2004) Type I interferon production enhances susceptibility to Listeria monocytogenes infection. J Exp Med 200(4): 437-445.

38. Stockinger S, Reutterer B, Schaljo B, Schellack C, Brunner S, et al. (2004) IFN regulatory factor 3dependent induction of type I IFNs by intracellular bacteria is mediated by a TLR- and Nod2independent mechanism. J Immunol 173(12): 74167425.

39. Stockinger S, Kastner R, Kernbauer E, Pilz A, Westermayer S, et al. (2009) Characterization of the interferon-producing cell in mice infected with Listeria monocytogenes. PLoS Pathog 5(3): e1000355.

40. Henry T, Brotcke A, Weiss DS, Thompson LJ, Monack DM (2007) Type I interferon signaling is required for activation of the inflammasome during Francisella infection. J Exp Med 204(5): 987-994.

41. Manca C, Tsenova L, Freeman S, Barczak AK, Tovey M, et al. (2005) Hypervirulent M. tuberculosis W/Beijing strains upregulate type I IFNs and increase expression of negative regulators of the Jak-Stat pathway. J Interferon Cytokine Res 25(11): 694-701.

42. Ordway D, Henao-Tamayo M, Harton M, Palanisamy G, Troudt J, et al. (2007) The hypervirulent Mycobacterium tuberculosis strain HN878 induces a potent TH1 response followed by rapid downregulation. J Immunol 179(1): 522-531.

43. Remoli ME, Giacomini E, Lutfalla G, Dondi E, Orefici G, et al. (2002) Selective expression of type I IFN genes in human dendritic cells infected with Mycobacterium tuberculosis. J Immunol 169(1): 366-374.

44. Mancuso G, Midiri A, Biondo C, Beninati C, Zummo S, et al. (2007) Type I IFN signaling is crucial for host resistance against different species of pathogenic bacteria. J Immunol 178(5): 3126-3133.

45. Parker D, Martin FJ, Soong G, Harfenist BS, Aguilar JL, et al. (2011) Streptococcus pneumoniae DNA initiates type I interferon signaling in the respiratory tract. MBio 2(3): e00016-e00111.

46. Weigent DA, Huff T L, Peterson JW, Stanton GJ, Baron $S$ (1986) Role of interferon in streptococcal infection in the mouse. MicrobPathog 1: 399-407.

47. Watanabe T, Asano N, Fichtner-Feigl S, Gorelick PL, Tsuji Y, et al. (2010) NOD1 contributes to mouse host 


\section{Journal of Infectious Diseases \& Travel Medicine}

defense against Helicobacter pylori via induction of type I IFN and activation of the ISGF3 signaling pathway. J Clin Invest 120(5): 1645-1662.

48. Kelly-Scumpia KM, Scumpia PO, Delano MJ, Weinstein JS, Cuenca AG, et al. (2010) Type I interferon signaling in hematopoietic cells is required for survival in mouse polymicrobial sepsis by regulating CXCL10. J Exp Med 207(2): 319-326.

49. Weighardt H, Kaiser-Moore S, Schlautkotter S, Rossmann-Bloeck T, Schleicher U, et al. (2006) Type I IFN modulates host defense and late hyperinflammation in septic peritonitis. J Immunol 177(8): 5623-5630.

50. Martin FJ, Gomez MI, Wetzel DM, Memmi G, O'seaghdha M, et al. (2009) Staphylococcus aureus activates type I IFN signaling in mice and humans through the $\mathrm{Xr}$ repeated sequences of protein $\mathrm{A}$. J Clin Invest 119(7): 1931-1939.
51. Al Moussawi K, Ghigo E, Kalinke U, Alexopoulou L, Mege JL, et al. (2010) Type I interferon induction is detrimental during infection with the Whipple's disease bacterium, Tropheryma whipplei. PLoS Pathog 6(1): e1000722.

52. De Almeida LA, Carvalho NB, Oliveira FS, Lacerda TL, Vasconcelos AC, et al. (2011) MyD88 and STING signaling pathways are required for IRF3-mediated IFN-beta induction in response to Brucella abortus infection. PLoS One 6(8): e23135.

53. Patel AA, Lee-Lewis H, Hughes-Hanks J, Lewis CA, Anderson DM (2012) Opposing roles for interferon regulatory factor-3 (IRF-3) and type I interferon signaling during plague. PLoS Pathog 8(7): e1002817.

54. Furuya Y, Steiner D, Metzger DW (2014) Does Type I Interferon Limit Protective Neutrophil Responses during Pulmonary Francisella Tularensis Infection? Front Immunol 5: 355. 